\title{
World's First Known Written Word at Göbekli Tepe on T-Shaped Pillar 18 Means God
}

\author{
Manu Seyfzadeh, Robert Schoch \\ Institute for the Study of the Origins of Civilization, College of General Studies, Boston University, \\ Boston, MA, USA \\ Email: manu@cheopspyramid.com,schoch@bu.edu
}

How to cite this paper: Seyfzadeh, M., \& Schoch, R. (2019). World's First Known Written Word at Göbekli Tepe on T-Shaped Pillar 18 Means God. Archaeological Discovery, 7, 31-53.

https://doi.org/10.4236/ad.2019.72003

Received: January 10, 2019

Accepted: January 29, 2019

Published: February 1, 2019

Copyright () 2019 by author(s) and Scientific Research Publishing Inc. This work is licensed under the Creative Commons Attribution International License (CC BY 4.0).

http://creativecommons.org/licenses/by/4.0/

\section{(c) (i) Open Access}

\begin{abstract}
Göbekli Tepe is a prehistoric, man-made megalithic hill site in today's southeast Turkey which is riddled with walled circular and rectangular enclosures lined by and surrounding T-shaped monolithic pillars proposed to represent supernatural humanoid beings. We examined if $\mathrm{H}$-shaped carvings in relief on some of these pillars might have a symbolic meaning rather than merely depicting an object of practical use. On Pillar 18 in Enclosure D, for example, one such " $\mathrm{H}$ " is bracketed by two semi-circles. An almost identical symbol appears as a logogram in the now extinct hieroglyphic language of the Bronze Age Luwians of Anatolia and there it meant the word for "god". Further supporting a linguistic connection between Luwian hieroglyphs and images at Göbekli Tepe are to date untranslated Luwian symbols resembling the T-shape iconography of Göbekli Tepe and an H-like symbol which was the Luwian word for "gate". We conclude that the T-shaped pillars at Göbekli Tepe were in fact built and symbolically marked to represent a god, possibly a bull-associated being, which guarded the entry to the human and animal afterlife. We propose that this theme may have been inspired by real celestial images of the then prevailing night sky, ritually reenacted and celebrated for centuries by hunter-gatherer pilgrims to this hill and then spread by their descendants across Anatolia still influencing language in the region spoken and written thousands of years later.
\end{abstract}

\section{Keywords}

Göbekli Tepe, Luwian, Hieroglyphic, Anatolia, T-Shaped Pillar, Pillar 18, Enclosure D, God

\section{Introduction}

Origin of Writing. The invention of writing is commonly attributed to Sumer 
and Egypt and the earliest evidence of either language dates to the late fourth millennium B.C.E. (Damerow, 2006). The first alphabet was created from Egyptian hieroglyphs by Canaanite miners in Sinai approximately one thousand years later at the beginning of the second millennium B.C.E. (Goldwasser, 2016). While the terminus ante quem of the origin of writing in the world can thus be traced to the Chalcolithic Age of Egypt and Mesopotamia, prehistoric civilizations may have expressed thought as recorded symbols long before, but evidence of such early writing may have been lost due to the decay of the medium, due to cultural invasion and replacement, or may yet be discovered. For example, traces of a pictographic script used in predynastic Buto and the region of the Nile Delta at large survived as hieroglyphic symbols in the mixed phonetic and ideogrammic script of dynastic Egypt while the rest of the language was apparently phased out by the time of Horus Den during the First Dynasty (Helck, 1987, Chapter 11, page 138).

The oldest recording system to date appears to have been clay tokens used to account for food stores which were discovered at Tell Mureybet by the western Euphrates in that site's layer III whose beginnings date to circa 9300-8600 B.C.E. (Senner, 1991: pp. 29-30). From this discovery and others, a widely-held model of cultural evolution by $20^{\text {th }}$ century archeologists implies that written language was invented after the development of agriculture based on the domestication of plants and livestock, and thus, like urban living, social stratification, and religion, represents an expression and outgrowth of materialistic culture, the ultimate driving force of cultural change in this model. The two main successive phases of this change from prehistoric hunter-gatherers to ancient historic dynastic city-state or nation dwellers were originally defined as the Neolithic and Urban Revolutions by V. Gordon Childe (Smith, 2009).

Jacques Cauvin (2000), however, who led France's CNRS-sponsored excavations at Tell Mureybet in the mid-1970s, proposed the antithesis to this model by Childe: That symbolic thought and a belief system did not only predate domestication of food sources and the sedentary life-style of permanent settlements, but that it was instrumental in fostering them. In other words, the Neolithic revolution, according to Cauvin, was first and foremost a prehistoric revolution of the world-view of the people alive in that epoch at the end of the ice age in the $10^{\text {th }}$ millennium B.C.E. It was this new world-view which shaped the insight to cope with a changing environment by employing a new life-style based on farming and settling in larger communities. Thus, ideologic or spiritual belief, first, enabled inventive thinking, second. Prehistoric people needed a reason to congregate. Once that happened, innovation and implementation became more likely when many people, previously physically separated, exchanged ideas, worked together, and shared the toil of living. In modern economics, this phenomenon is called agglomeration. Recorded symbolic language, like world-view and spirituality, could thus also be considered an expression of such new awareness, besides sculpture, architecture, and murals, made long before food was 
grown and stored and needed to be accounted for. Symbolic, "religious" thinking and expanded awareness may even have been a requisite (Hodder, 2011: p. 112).

Given that the origin of the Indo-European branch of languages can be traced both to Anatolia and to a timeframe which overlaps with the aceramic Neolithic era (Bouckaert et al., 2012), megalithic monuments from this place and time may hold clues as to the need to capture spoken language with symbols and preserve them in stone for later generations (Schoch, 2012: p. 41). This need may have arisen with a desire for permanence beyond death and a sentiment for ancestry evident in the practice of skull removal of the buried dead, artistic modifications to human skulls (as found on human skull fragments at Göbekli Tepe; Gresky et al., 2017), and circulating them throughout the community as is evident from the archeological record at Çatalhöyük (Hodder, 2011: pp. 114-116). In this paper, we will present primordial evidence of pre-agricultural symbolic language related to the religious beliefs of an early Neolithic society of so-called "hunter-gatherers"1 in southeast Anatolia at Göbekli Tepe. Our investigation, however, begins with an examination of hieroglyphic Luwian, a language in use across most of Bronze Age Anatolia thousands of years after prehistoric people built Göbekli Tepe.

Luwian Hieroglyphic Script. The Luwian hieroglyphic script, while discovered in the early $19^{\text {th }}$ century, was fully deciphered only in the 1970 s and shown to be a close dialect of cuneiform Luwian and a sister language of cuneiform Hittite, the official script of the ruling class of Bronze Age Anatolia during the Empire Period (circa 1200-1000 B.C.E), which it both preceded and survived by centuries (Goedegebuure, 2016, 2107). Thus, Luwian is one of the oldest, if not the oldest, known Indo-European languages and a likely descendant of the hypothetical Proto-Indo-European (PIE) common ancestor of all members of this language family. Current archeological evidence in the form of seals, reliefs, steles, lead strips, and wood panels, across almost one-hundred Anatolian sites, including some within $30 \mathrm{~km}$ of Göbekli Tepe, dates the emergence of the hieroglyphic script used to write in Luwian to the late $15^{\text {th }}$ century B.C.E., i.e. a time coinciding with Egypt's $18^{\text {th }}$ Dynasty of the New Kingdom, when Anatolia and Egypt interacted both in trade, diplomacy, and war. The Luwians, for example, may have been the "Sea People" with whom Ramses III fought, the Trojans with whom the Myceneans fought during Homer's Trojan War, and the confederate power which brought down the Hittites, all events occurring during the Late Bronze Age when several civilizations collapsed and recorded history entered a so-called Dark Age (Zangger, 2016).

Waal (2013) proposed an even earlier time of development of hieroglyphic

${ }^{1}$ It should be noted that "hunter-gatherers" may be a misnomer, because the builders of Göbekli Tepe were probably not equivalent to modern "hunter-gatherers" as discussed in the general anthropological literature; if anything, the Göbekli Tepe people may have been closer to so-called "complex hunter-gatherers" such as the Northwest Coast cultures of North America (see, for instance, Ames, 1994). 
Luwian, around 2000 B.C.E. Developed exclusively for the Luwian language, which together with Hittite, Lycian, Lydian, Palaic, and Carian comprises the Anatolian branch of the Indo-European major language phylum, its origins can be traced to both spoken Hittite and Luwian (Figure 1). Some Luwian symbols encode full words in the form of logograms but most encode phonographic sounds. In the latter case, the phonetic values still relate to the pictographic idea of the symbols through acrophony, i.e. the sounds of the script's phonographic symbols are defined by the beginning of the sound of the words whose ideas they depict. For example, the Luwian word for walk "tia" produces the phonetic syllable "ti" encoded by a foot symbol. The Luwian word for ox "uwa" produces the phonetic sound "u" encoded by an ox head symbol. The Luwian word for donkey "tarkasna" produces the phonetic syllabic sound "ta". Some Luwian hieroglyphic symbols obtained their phonetic value not from the Luwian spoken language but from Hittite words. It is this bilingual origin of the script which suggests that the region of its invention was in eastern Anatolia where both languages were spoken (Figure 1; Goedegebuure, 2016).

The development of the script over time also suggests that it started with pictographs and that phonograms were gradually added later. This development contrasts with Egypt's proto-dynastic writing system which incorporated phonograms in its earliest known records discovered in tomb UJ (Baines, 2004). We therefore asked if the Luwian script, at its inception, may have incorporated surviving themes and especially symbols (i.e. iconic pictographs) of the long-gone

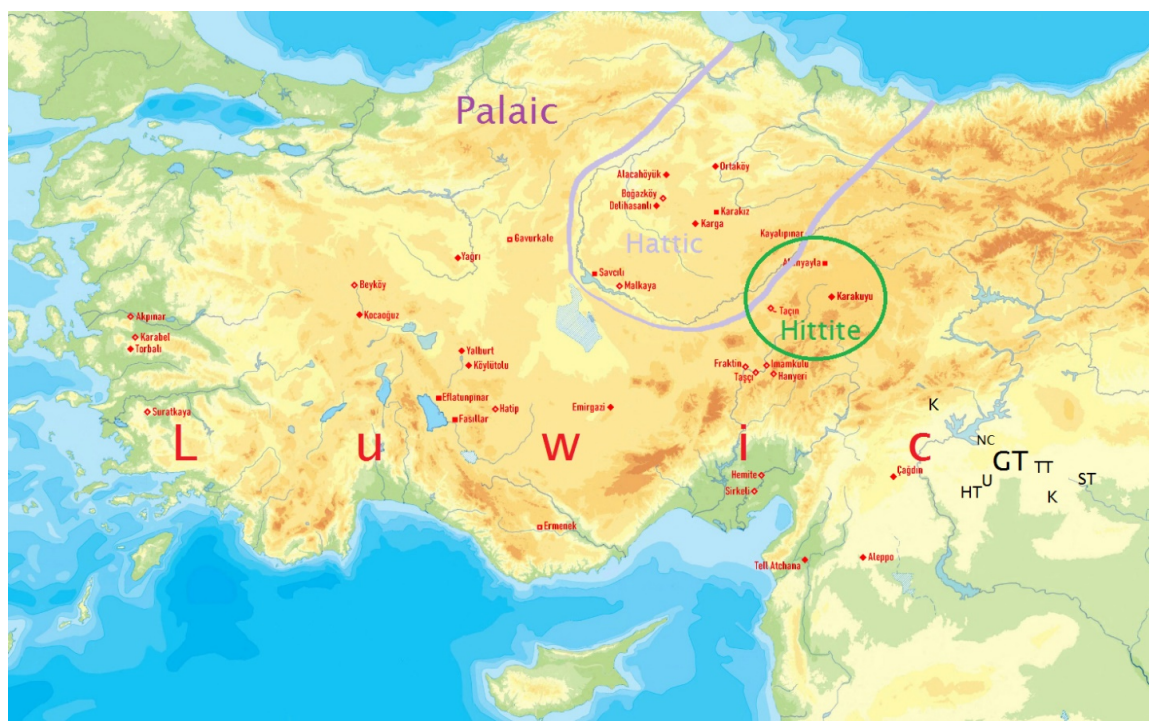

Figure 1. Map of ancient Anatolia showing the locations of Luwian (Luwic) writing discovered from the Empire Period (circa 1480-1200 B.C.E.). Megalithic sites with T-shaped Pillars west and east of the Euphrates River are indicated in black letters. GT: Göbekli Tepe; NC: Navali Çori; U: Urfa; HT: Hamzan Tepe; K: Karahan; ST: Sefer Tepe; TT: Tašli Tepe; K: Kilisik. Four language zones are marked. Palaic, Hattic, Hittite, and Luwic (Luwian). The overlap between Hittite and Luwic occurred in the zone approximated by the green circle. Map courtesy of Tayfun Bilgin, https://www.hittitemonuments.com, (v. 1.61), modified. 
people who had lived nearby in southeast Anatolia and had built one of the oldest known megalithic complexes in the world from which the Neolithic Revolution expanded across the fertile crescent and eventually further into the continents of Europe, Asia, and possibly parts of Africa and elsewhere.

Göbekli Tepe. Göbekli Tepe Layer III is a Neolithic Pre-Pottery, megalithic phase at a prominent and widely visible location in the upper Euphrates Valley zone, which makes up the northern extent of the fertile crescent marking the transition between ancient Mesopotamia's plains to the southeast and Anatolia's mountainous highlands to the northwest. The complex was built on a limestone ridge over a period of about 800 or more years in the $10^{\text {th }}$ and $9^{\text {th }}$ millennia, further extended with ancillary structures in Layer II for a period of 1800 years during the $9^{\text {th }}$ and $8^{\text {th }}$ millennia, and then completely buried and abandoned by circa 7000 B.C.E. (Schmidt, 2000, 2011, 2012). Originally discovered as a possible site of interest in 1963 by the Universities of Istanbul and Chicago led by Halet Çambel and Robert Braidwood, respectively, it was found to be a very ancient megalithic site in 1994 during initial excavations undertaken by the German Archeological Institute's late Klaus Schmidt (Schmidt, 2000, 2011). Schmidt's excavations over the years into this man-made hill unearthed several stone circles surrounding, and lined with, T-shaped pillars (Figure 2) onto which animal figures and, as he had already witnessed at Navali Çori, humanoid features like arms and hands were carved in relief (Figure 3(a)), for example on Pillar 18 at the center of Enclosure D in the hill's southeast quadrant (Figure 3(b) \& Figure 3(c)).

Pillar 18 rests on a pedestal with bird reliefs on its façade (Figure $3(\mathrm{c})$ ). Besides a foxlike animal on its "torso" (Figure 3(b)), it features a finely carved belt with several "H"-shaped symbols (Figure 3(g) \& Figure 3(h)) and a buckle from which an animal hide loincloth hangs (Figure $3(\mathrm{c})$ ). At the top front of the pillar is a set of three symbols composed (from top to bottom) of another "H"-shaped symbol and an umbilicated disc hovering within the concavity of a

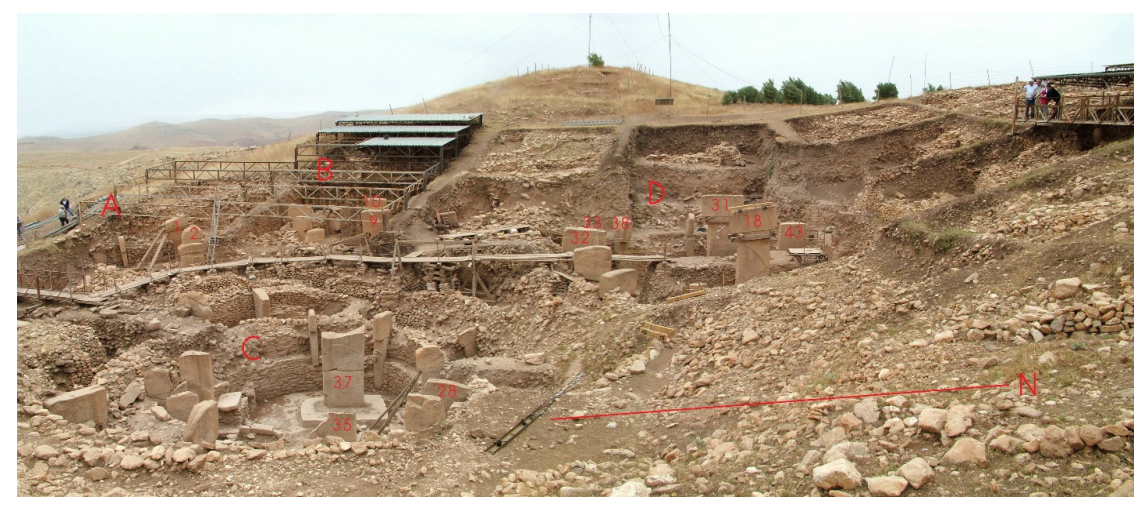

Figure 2. Göbekli Tepe's Layer III site plan looking west from the east with north to the right in this image. Four enclosures are shown, and their conventional designations A, B, $\mathrm{C}$, and $\mathrm{D}$ are indicated above. All eight central pillars and some of the peripheral pillars are marked including all those discussed in this paper. Pillar 33 in Enclosure D is nestled between Pillars 32 and 38 and is not fully visible in this image. Composite image courtesy of Robert Schoch and Catherine Ulissey. 

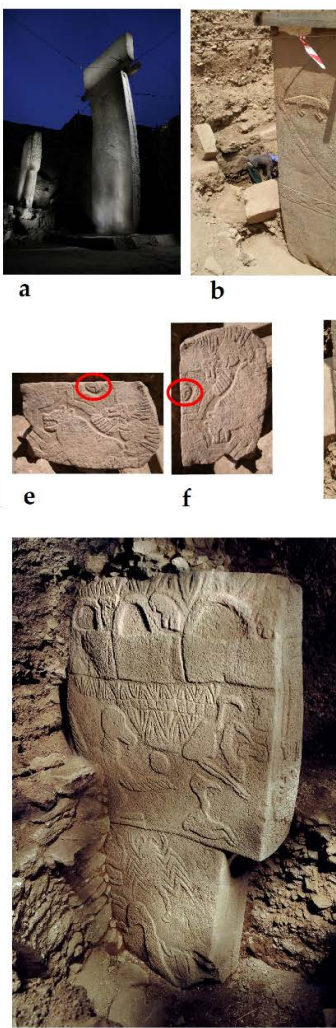
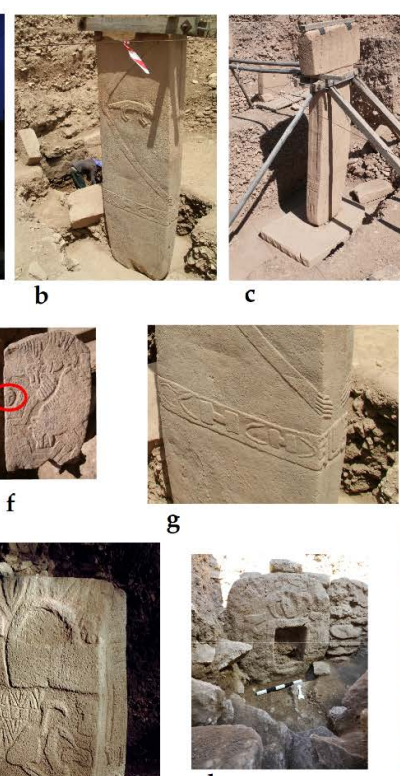

k

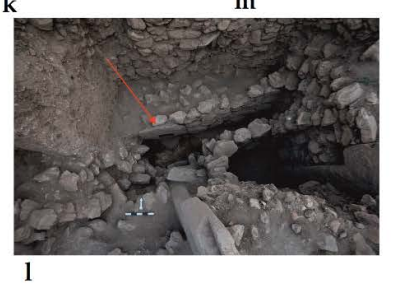

h

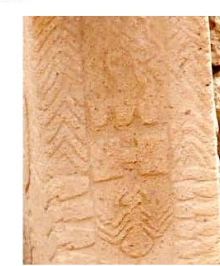

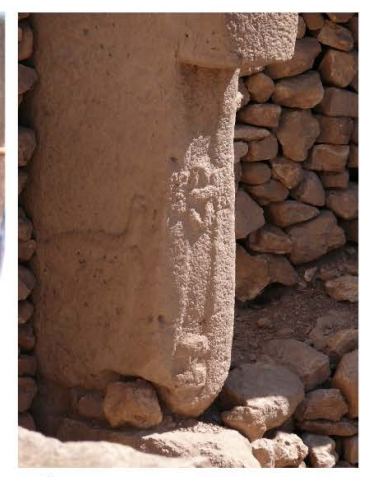

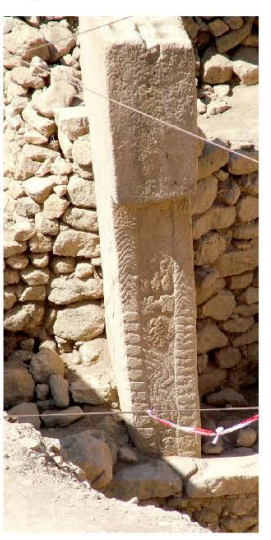

n

Figure 3. Central and peripheral pillars, limestone plate, and porthole, Göbekli Tepe, Turkey. (a) Pillar 31 and (b-d; g-h) Pillar 18, from Enclosure D; (e-f) carved limestone plate found by Pillar 31 showing severed heads (marked in red by D.A.I.); (i) Pillar 28 from Enclosure C; (j) Pillar 43 from Enclosure D; (k-1, red arrow in (l) by D.A.I.) Porthole stone close-up and in situ from above, Enclosure B; (m-n) Pillar 33 from Enclosure D. Images courtesy of Robert Schoch and Catherine Ulissey (b-d, g-i, m-n), Berthold Steinhilber (j) and the German Archeological Institute (D.A.I., a, e-f; D.A.I.'s N. Becker, k-l) with permission.

crescent (Figure 3(d)). Of note, the "head" of the pillar is unmarked, though there are other pillars whose topmost parts are ornately carved with animal and geometric motifs. No facial features have been found on any pillar unearthed to date. The significance of the T-shape and its association with humans remain a mystery, but most agree that supernatural beings were meant to be displayed in stone.

Within the back-fill debris surrounding Pillar 31, the other megalith in the center of Enclosure D next to Pillar 18, a limestone plate with reliefs showing severed heads (Figure 3(e) \& Figure 3(f); marked with red circles) next to a vulture and also two life-size human limestone heads were discovered demonstrating that the humanoid T-shape of the pillar heads was deliberately chosen to contrast with the realism of the human heads. Seemingly complementing the severed heads by Pillar 31 (see Gresky et al., 2017: p. 5, their Fig. 4a, for a photograph of a decapitated human statue from Göbekli Tepe), a small headless torso is depicted in relief at the bottom of Pillar 43's west-facing side (at the bottom of 
the pillar, again next to a vulture; Figure $3(\mathrm{j}))$. Pillar 43 was integrated within the enclosure wall immediately behind Pillar 31 (see Figure 2) to the northwest (the enclosure wall is most likely of a later period-that is secondary-relative to the pillars; see Schoch, 2017: p. 458). The headless torso on Pillar 43 appears small next to the much larger animals also shown (Figure 3(j)), for example a vulture immediately next to it. These motifs of vultures and headless human torsos reappear two-thousand years later on murals of a temple-like structure at Çatalhöyük hundreds of kilometers to the west demonstrating their cultural importance (Sandars, 1979).

While the purpose of the entire complex at Göbekli Tepe, still largely unexcavated, continues to be debated, the anthropomorphic yet "alien" character of the over-sized T-pillars suggests that they depict supernatural beings or gods and that the site therefore had a spiritual congregational function though other, possibly more secular, purposes cannot yet be ruled out given, for instance, evidence of feasting and other activities at the site (see, e.g., Banning, 2011). T-shaped pillars have also been discovered at nearby sites east and west of the Euphrates, i.e. Navali Çori, Urfa, Hamzan Tepe, Karahan, Sefer Tepe, Tašli Tepe, and Kilisik, with Göbekli Tepe assuming the central focus of this cultural zone (Figure 1).

Symbolism and Meaning. The meaning of the animal depictions and other relief markings on the T-pillars, as well as the pillars themselves and the circles they form, remain a mystery to date and while several theories have been proposed, such as relating them to Orion's belt stars (Schoch, 2012: pp. 54-55), to stars in the north (Deneb; Collins, 2014: pp. 80-82), Sirius (Magli, 2013, 2016), or foreign symbols (e.g. Putney, 2014), unequivocal proof remains elusive. The fact that dwellings at Çatalhöyük were found to contain adult burials always on the north side of the living space (Hodder, 2012: p. 305) sometimes marked by aurochs skulls and often by vulture paintings with headless corpses (Hodder, 2012: p. 306), lends support to the hypothesis that the approximate north-south orientation of most of Göbekli Tepe's T-pillar circles may be integral to the ideas which inspired their construction. The central T-pillars themselves may represent a god or gods "looking" out to the sky at a bull (for instance, Taurus) or associated with a bull (for instance, Orion, who is in the same general portion of the sky as Taurus; see Schoch, 2012: p. 55). Virtually all the other animals depicted on the pillars and associated stone carvings, i.e. snakes, lizards, spiders, scorpions, foxes, boars, lions, leopards, and various birds including a vulture, cranes, and an eagle were indigenous to the regional fauna of Holocene southeast Anatolia (Schmidt, 2011, 2012).

Klaus Schmidt interpreted Göbekli Tepe as a ritual center to which hunter-gatherers from surrounding settlements congregated to feast and commemorate or even bury some of their significant dead but did not rule out a shamanic purpose (Schmidt, 2011, 2012). He read the pillar carvings as a form of storytelling while the high-relief animal sculptures had a symbolically protective function. He emphasized the significance of the symbolic dominance of the human 
features of the megaliths over those of the fear-instilling animals and singled out Göbekli Tepe as unique in this respect among other contemporary Neolithic sites. To Schmidt, Göbekli Tepe's main theme was the conquest by man-like gods of the wilderness world and this spiritual theme unmistakably predated the pragmatically driven transition from hunting and gathering for food to growing and storing it as the changing environment after the Younger Dryas may have dictated.

Here, we present new evidence that one, especially peculiar, carving may represent a written symbol, as previously suspected (Ercan, 2015), which identifies one of the most prominent and central of the T-pillars as a deity and thus supports the idea that Göbekli Tepe was in fact a temple complex ${ }^{2}$ dedicated to at least one god which formed perhaps a symbolic gateway to the afterlife as well as protecting the still living. We discuss the possible origins of this symbol, its significance within the ritual context of the entire site, which may have its origins in imagined celestial images.

\section{Results}

One often-appearing Luwian symbol is the word for "god", Laroche \#360 "DEUS3" (Figure 4; Laroche, 1960). Many examples can be observed at the almost one-hundred sites from which written records were discovered. This symbol depicts an oval with two opposing semi-circles and two vertical parallel lines between them. For example, it is well shown on rock inscriptions in Develi by Fraktin (Figure 5) and from Arslan Tepe (Figure 6) and several instances of it can be seen on a storm god stele from Aleppo (Figure 7). At Hanyeri, a symbolic association can be observed between "DEUS" and "MONS", where both are used on the same line of text translated as "king of the mountain god" (Figure 8). Close inspection of "MONS" (Figure 9), reveals that the only difference to "DEUS" are the long converging lines in "MONS" separating its opposing semi-circles as opposed to the two parallel vertical lines separating them in "DEUS".

The "H"-shaped Luwian symbol is the logogram for PORTA ("gate"; Petra Goedegebuure, personal communication) and is seen in detail for example in an inscription from Arslan Tepe (Figure 10). There are "T"-shaped Luwian symbols, the meaning of which still eludes translation. One such symbol, Laroche \#457 (2) (Figure 11) shows a "T" on a steep mount. An example can be seen in situ at Sivasa (Figure 12).

\section{Discussion}

Linguistic link between Luwian and Göbekli Tepe's Iconography. It appears that when the Luwian script was invented, it adopted some Anatolian icons predating its inception (between 2000 and 1400 B.C.E.) by thousands of years. Since

${ }^{2}$ Whether solely a "temple complex", as Göbekli Tepe is often referred to, or something more, such as the equivalent of a center of learning, ritual, teaching, and protecting traditions and knowledge, is a subject that is up for discussion based on further evidence.

${ }^{3}$ Luwian logograms are translated into Latin by convention. 
360 (बD "DIEU."

Variantes: ब(ब) बाम

1. Déterminatif divin.

Yazilikaya $43:{ }^{d} H e-p a-t u$ "Hebat »; $42:{ }^{\mathrm{d}} \mathrm{W}$ CIEL "Tešub (du) ciel »;

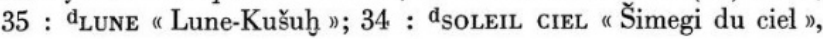
etc.

Karatepe $13:{ }^{\mathrm{d}} \mathrm{w}-h u-i-s ~ " T a r h u n d a 》=$ phén. $B^{c} l$.

Kargamis, A 11 a $6:{ }^{\mathrm{d}_{\mathrm{W}-s}{ }^{d} K a ́}+r$-hu-há-s ${ }^{d} K u$-OISEAU-pa-s-há "Tarhunda, Karhuha et Kubaba ».

Hamath V $1:{ }^{d} B a-h a ́-l a-t i$-sà-pa-wa TEMPLE $+m i-i$ « et le temple de Ba alat".

Karadağ $1:{ }^{d}$ GRANDE MONTAGNE.

2. Id. «dieu, déesse»; compl. phon. -na-

Hanyeri, gauche : (1) RoI (de la) MONTAGNe-Divine ${ }^{d}$ Sarruma.

Karatepe $54=54^{\prime}$ et suiv. : ${ }^{\mathrm{d}} \mathrm{W}-h u-t a_{4}-t i_{4}$ DIEU-na- $a+t a / i$-há "grâce

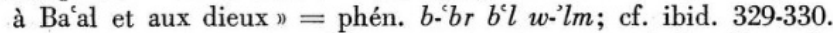
- 288 et suiv. : FORT. $h a+r-n a-s ́ a-s a ́$ DIEU-ná-i «les dieux de la forteresse » = phén. 'ln qrt; $289^{\prime}$ : DIEU-sa $a_{4} !-i$.

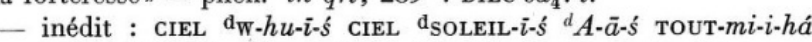
DIEU-ná-i "Ba'al des cieux, Soleil du ciel, Aa et tous les dieux»= phén. $w$ - $k l d r b n$ ' $l m$.

Figure 4. Laroche \#360 Luwian hieroglyph denoting “god”. From Laroche (1960: p. 187).

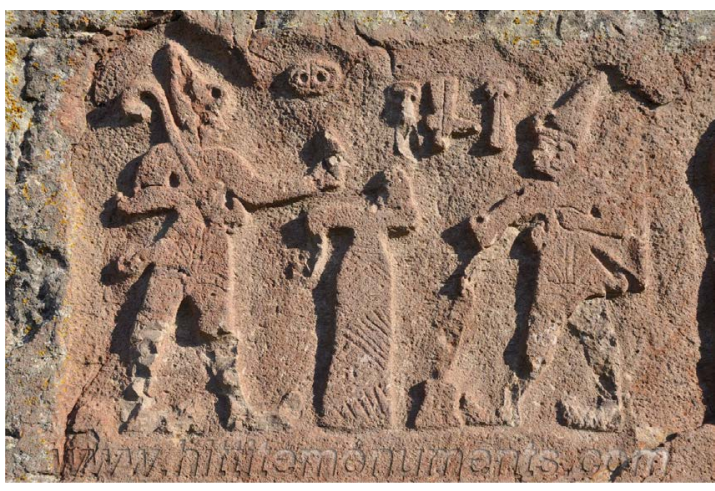

Figure 5. Luwian rock inscription, Gümüşören (Fraktin) village of Develi, circa 1300-1200 B.C.E. The "god" symbol Laroche \#360 is shown at the top next to the head of the figure on the left. Image courtesy of Tayfun Bilgin, https://www.hittitemonuments.com, (v. 1.61).

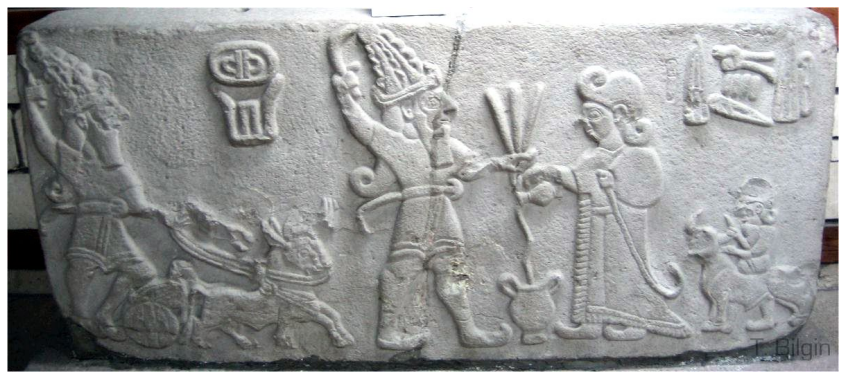

Figure 6. Luwian rock inscription from Arslan Tepe at the Anatolian Civilizations $\mathrm{Mu}$ seum in Ankara, Turkey; circa 900 B.C.E. The "god" symbol Laroche \#360 is shown at the top next to the head of the storm god (Tešup) figure on the left. Immediately below is the logogram for "lightning", Laroche \#199. Image courtesy of Tayfun Bilgin, https://www.hittitemonuments.com, (v. 1.61). 

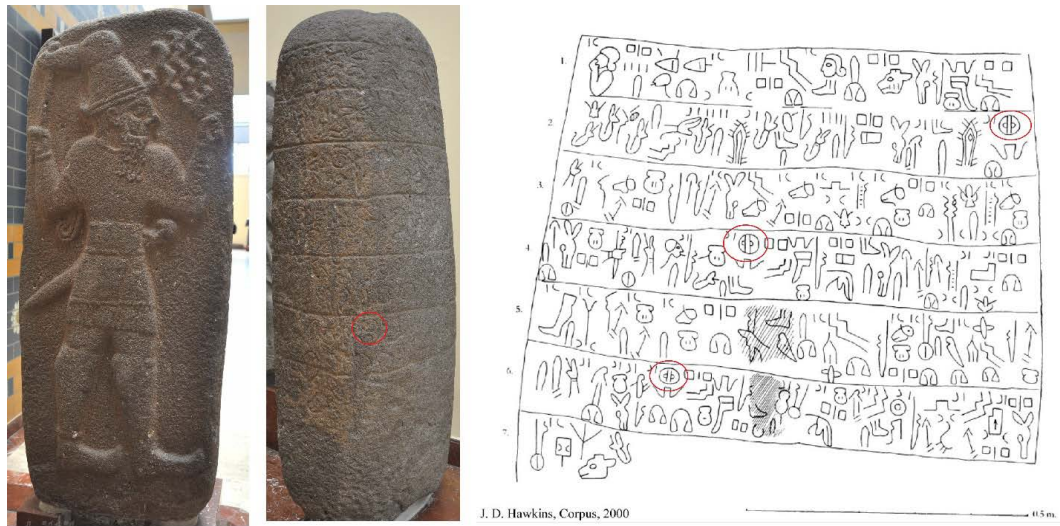

Figure 7. Storm God Relief and Stele from Aleppo, Istanbul Archeology Museum. Marked with red circles are instances of Laroche \#360 on the stele and its transcription. Images courtesy of Tayfun Bilgin, https://www.hittitemonuments.com, (v. 1.61), modified.
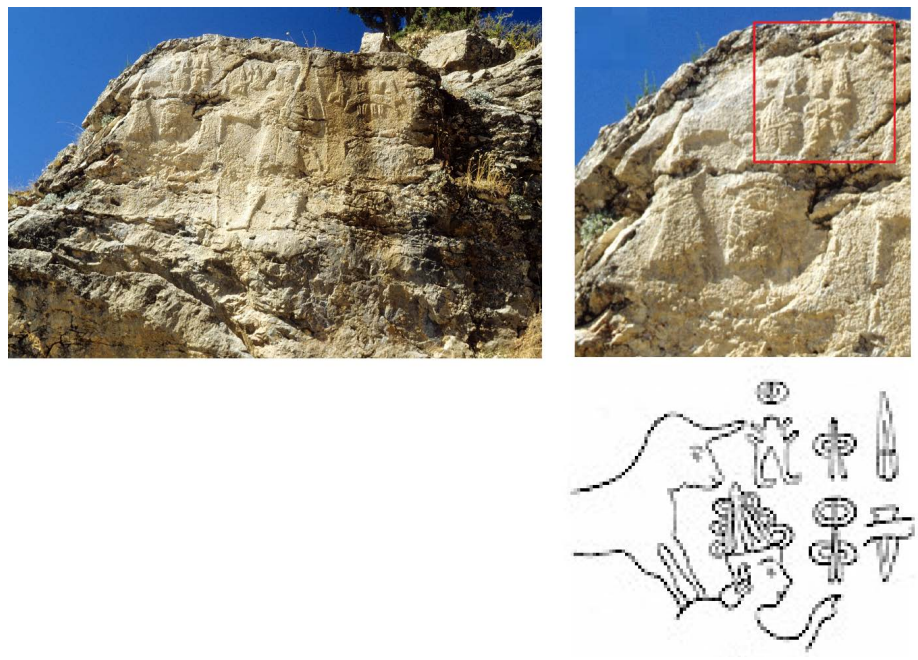

Figure 8. Luwian rock inscription at Hanyeri, circa 1300-1200 B.C.E. The three-part relief is shown on the left and the magnified left part on the top right. Below is the transcription. The top row of symbols reads from right to left: "King of the Mountain god, Sharruma" (REX MONS DEUS.SARMA) and the second row reads "Sword, the divine mountain” (ENSIS DEUS.MONS). Images and graphic courtesy of Tayfun Bilgin, https://www.hittitemonuments.com, (v. 1.61), modified.

\section{7}

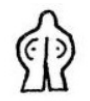

1. “MONTAGNE. »

2. $w a_{4}$.

Ligature de DIEU ( $\left.\mathrm{n}^{0} \mathbf{3 6 0}\right)$ et d'une montagne.

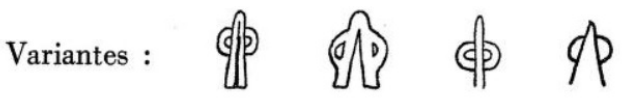

I. - Id. et déterminatif pour «montagne»; lect. phon. inconnue.

1. “ montagne (divine) ).

Hanyeri, gauche : (1) Ror (de la) MONTAgne ${ }^{d}$ Sarruma (2) $53{ }^{\text {d }}$ MONTAGNE : désignent l'animal et l'être anthropomorphe.

Figure 9. Laroche \#207 Luwian hieroglyph denoting “Mountain”. From Laroche (1960: p. 112). 


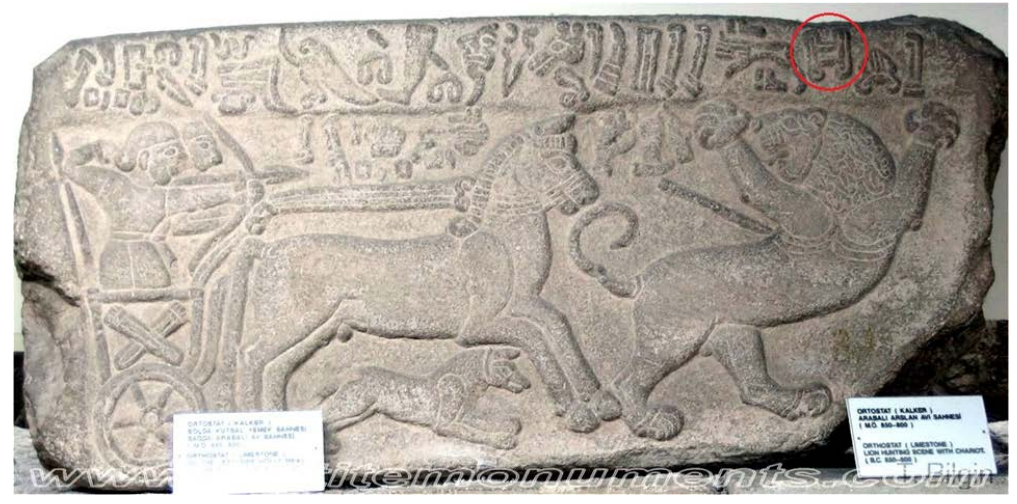

Figure 10. Luwian rock inscription from Arslan Tepe at the Anatolian Civilizations $\mathrm{Mu}$ seum in Ankara, Turkey; circa 1100-1000 B.C.E. The " $\mathrm{H}$ "-shaped symbol is shown marked in red. Image courtesy of Tayfun Bilgin, https://www.hittitemonuments.com, (v. 1.61), modified.
239

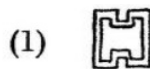

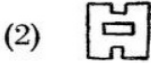
(3)

(1) Emirgazi $1.4=2.1=3.2:$ 239-mi; ibid. $1.5=2.2=3.3:$ 239-mi-pi.

(2) Karahöyük-Ełbistan $11: \mathbf{2 3 9 - i}$.

(3) Maraş, 8.5 : 239-i.

Selon Hrozný, IHH (1937) 412 et suiv. : « porte ».

261

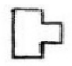

Sorte de bâtiment?

1. Id. verbal; compl. phon. -taru-, sens incertain : "bâtir?".

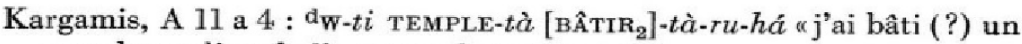
temple au dieu de l'orage n; de même A 2.4.

A 13 d 7 ; 25 a 1 : BÂTIR $\mathbf{2}^{-t a ̀-r u-t u ́, ~} 3^{\text {e }}$ sg. imp.

2. Id., verbal, compl. phon. -tapa, sens inconnu.

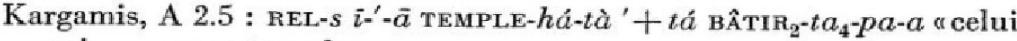
qui ... ra ce templen.

"Bâtir a chez Meriggi, Glossar (1934) 27, 99. - Rayer le "vestibule » de Hrozný, IHH (1935) 161, 206 n. 11, 221.

263

(1)

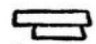

(2)

1. New York, Metr. Mus. 1 : 263-sa $a_{5}-a$, nom propre.

2. Karahöyük-Elbistan 10 : compl. ou lect. phon. -tá-na-sa $a_{5}$.

457
(1) 路) $l i_{4}$.
(2) 买

(1) Karatepe 31 : Jour $h a ́-l i_{4}-i=$ Jour $h a ́-l i-\bar{a}-\bar{\imath}, \mathrm{n}^{\circ} \mathbf{3 5 8}$.

(2) Suvasa D 1 : contexie obscur.

Selon Bossert, Oriens 1 (1948) 192, (1) = (2) $=458$.

Figure 11. Laroche \#239, 261, 263, and 457. \#457 (1) has the phonetic value of "li". \#239 translates into "Gate" and \#263 and \#457 (2) are unknown (Petra Goedegebuure, personal communication). \#261 is uncertain. From Laroche (1960: pp. 129, 137, 237); modified. 


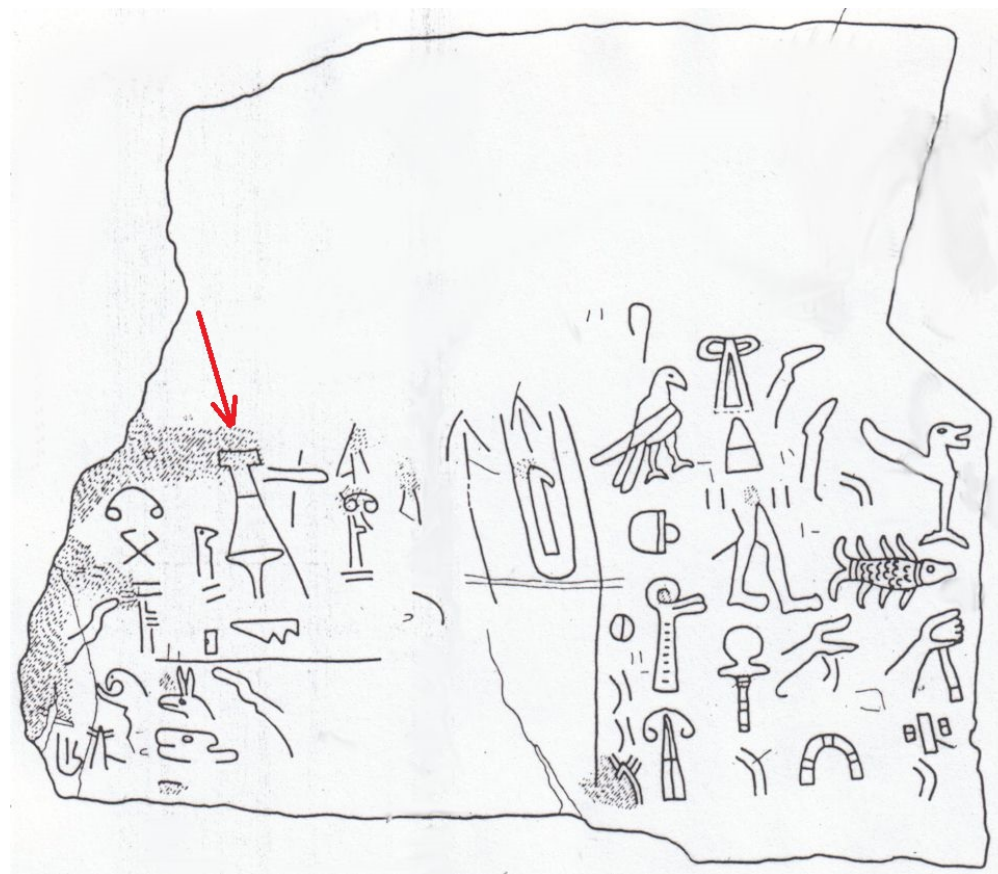

Figure 12. Transcribed Luwian rock inscription from a rock still in situ at Sivasa/Suvasa/Gökçetoprak. Laroche \#457 (2) is marked with the red arrow. Graphic courtesy of Tayfun Bilgin, https://www.hittitemonuments.com, (v. 1.61), modified.

Luwian contains, by our survey, at least four symbols directly related to iconography found at Göbekli Tepe, we think random chance is unlikely. However, even if Luwian adopted symbolic themes from its distant ancestors, we have to consider the more trivial scenario that people who lived in southeast Anatolia during the Bronze Age may have discovered decorated T-shaped pillars, ascribed importance to the symbolism of the pillars and some of the reliefs found on them, and consequently attached a meaning to these icons unrelated to that intended by the builders of Göbekli Tepe, which itself may be a trivial depiction of the details of a hunter's belt. The main reasons why we think this is unlikely are that: 1) the " $H$ " symbols occur both as part of the belt bracketed by semi-circles on Pillar 18 of Enclosure D, as a part of an apparently purely symbolic element on the front of Pillar 18 along with a disk inside a crescent, alone on the front of Pillar 28 in Enclosure C bracketed by two semi-circles (Figure 3(i)), and as a focal point for the direction of where animals are heading as shown on Pillars 43 and 33 in Enclosure D (Figure 3(j), Figure 3(m) \& Figure 3(n)), and 2) that this idea of a focal point is consistent with the concept of a gate, the meaning given to the " $H$ "-shaped symbol in Luwian. Therefore, it is possible that the original meaning behind Göbekli Tepe's iconography was verbally preserved in Anatolia's prehistoric and ancient legends and myths until a written script was made incorporating those prehistoric symbols along with their archetypal meaning.

The Luwian "god" symbol is not perfectly identical though close to the " $\mathrm{H}$ "-shaped symbol inside two semi-circles as seen on the belt of Pillar 18 (Figure 3(g)) and the chest of Pillar 28 (Figure 3(i)). The main difference is that 
the cross bar is missing, and the two vertical bars are closer together. Nevertheless, we think this Luwian iconography still preserves the concept of a passage, originally depicted blocked, then open in the Luwian symbol. The common position of Laroche \#360 in Luwian texts is at the top of a column of symbols within a row of text suggesting that the god so named was in the sky. One way to interpret the idea of a gate inside a circle in the sky is a passage through a vortex such as the celestial north pole of the night sky around which the circumpolar stars slowly wander each night and whose focal point gradually shifts due to the combined effects of axial and apsidial precession.

Our analysis does not reveal if the Luwian T-shaped symbols, Laroche \#261, 263, and 457 (2) (Figure 11) are words or sounds. However, the fact that an aurochs' cranium is depicted on the front of Pillar 31 in Enclosure D (Figure 3(a)), on top of the porthole of Enclosure B (Figure 3(k) \& Figure 3(1)), and on later Anatolian pottery decorations where the T-shape is evidently part of a bull head (Figure 13 and Figure 14) suggests that they represent the prehistoric word for "bull" or a syllable sound related to that word.

Spiritual Theme. Taken together, this evidence suggests that the T-shaped pillars at Göbekli Tepe were likely meant to represent a god in the form of a bull-like being. But what was its power or function within the context of circles? The answer to this question may come from the lay-out of the dwellings found at Çatalhöyük. There, the adult dead were commonly buried on the northeast side of the homes and sometimes marked with bucrania (Figure 15). This suggests the god in question was a guardian of the dead. In the same context, the vulture with the headless torso marked the north side of the dwelling. At Göbekli Tepe the general orientation of most circles unearthed so far is approximately south to north (Figure 16). The animals are shown to seemingly migrate towards the

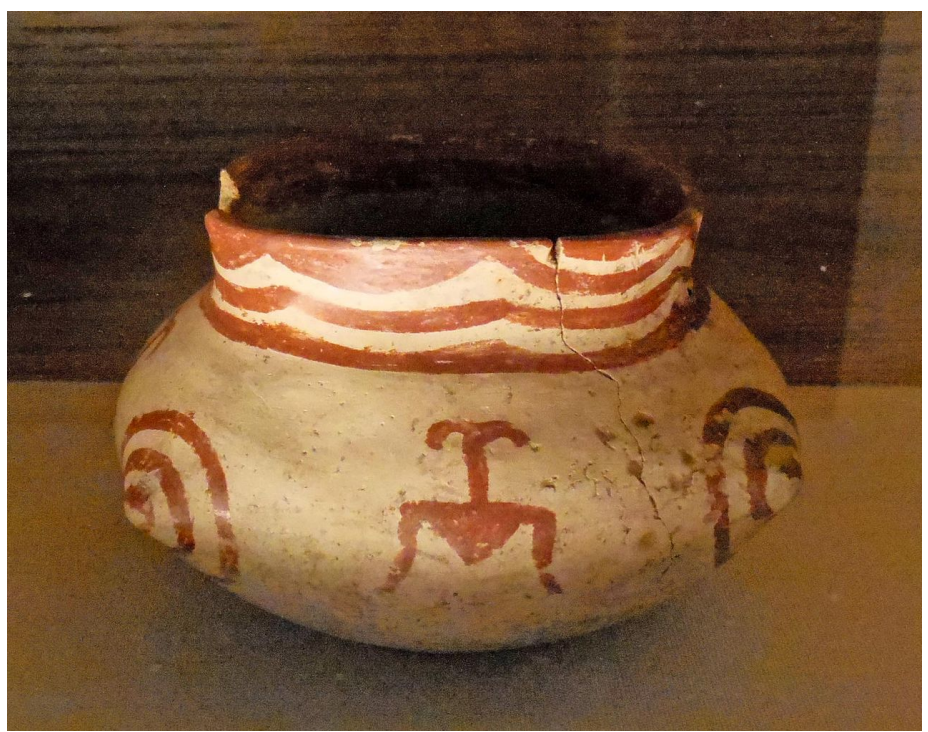

Figure 13. Terracotta vase from southwest Turkey at Haçilar, late $6^{\text {th }}$ millennium B.C.E. National Museum of Oriental Art, Rome, Italy. Photo courtesy of MM-Own work, CC BY-SA 3.0, https://commons. wikimedia.org/w/index.php?curid=29823064. 


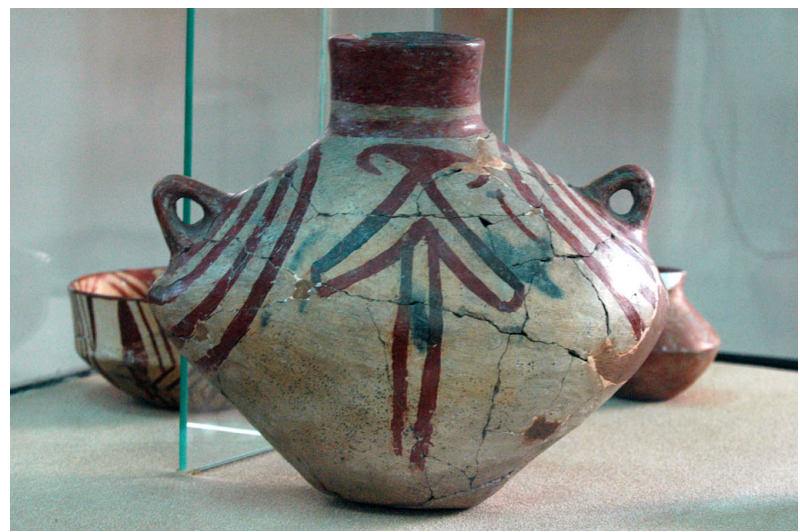

Figure 14. Decorated pottery from southwest Turkey at Haçilar, late $6^{\text {th }}$ millennium B.C.E. Ankara Anatolian Civilizations Museum, Ankara, Turkey. Image courtesy of Dick Osseman, with permission: http://www.pbase.com/dosseman/profile.

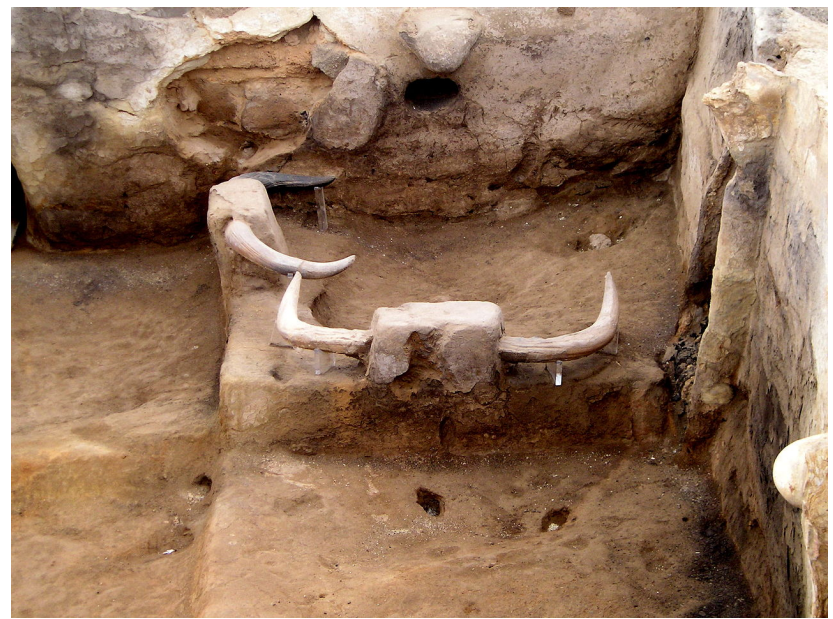

Figure 15. Northeast platform burial site in building 77 of the Pre-Pottery Neolithic B settlement in south Turkey at Çatalhöyük, $8^{\text {th }}$ to $7^{\text {th }}$ millennium B.C.E. Image courtesy of Verity Cridland-Çatalhöyük, CC BY 2.0,

https://commons.wikimedia.org/w/index.php?curid=7429553.

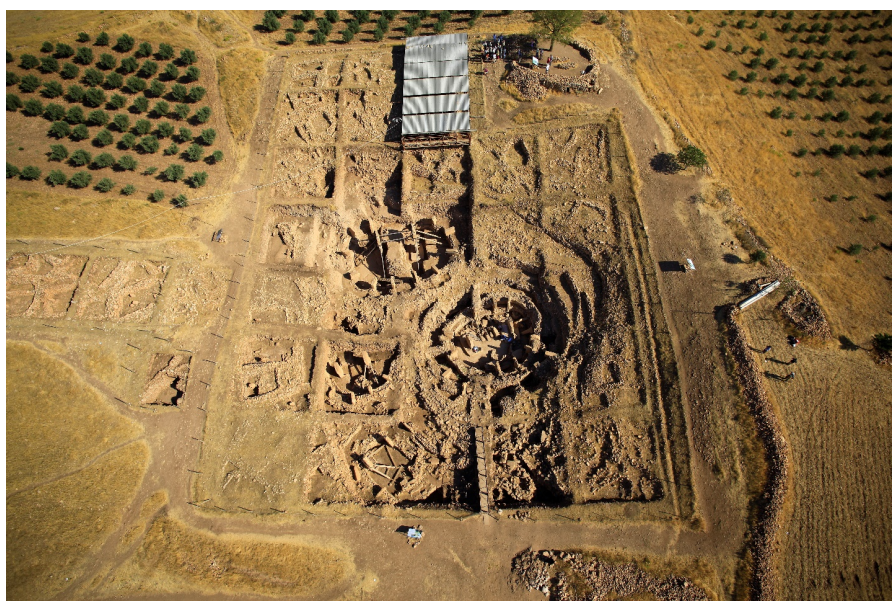

Figure 16. Aerial view of Enclosures A-D from the south looking north. Image courtesy of the German Archaeological Institute's (D.A.I.) E. Kücük, with permission. 
bull-like god represented, we argue, by the gate symbol " $\mathrm{H}$ ", and on the north side of Enclosure D, a vulture is shown next to a headless torso (i.e. the limestone plate found by Pillar 31, Figure 3(e) \& Figure 3(f), and Pillar 43 immediately northwest, Figure $3(\mathrm{j})$ ) in analogous fashion as to what is seen on north-wall murals inside dwellings at Çatalhöyük (Figure 17). Therefore, the view of the world suggested by this iconography could be interpreted as revolving around the inevitability of the death of all creatures, animals and humans, symbolized by the vulture and the headless torso, and that this passage from life to death involves an encounter with a god who stands at the gate of a passage (Collins, 2015) between life and death ${ }^{4}$. The discovery of limestone heads by Pillar 31, decorated fragments of human skulls at Göbekli Tepe, and plastered skulls at Çatalhöyük suggests that this word-view also made room for the notion of coming back to life (also suggested by Collins, 2014) and that this resurrected life spiritually resided inside of the head of the dead.

Astronomical Imagery. This idea of an $\mathrm{H}$-shaped gateway to the afterlife and the head as the seat of the life force may originate from what was visible in the night sky of the time. During the $10^{\text {th }}$ Millennium B.C.E., the north pole was occupied by the H-shaped constellation Hercules near the bright star Vega in the constellation Lyra next to Cygnus (Figure 18). We think this iconography of a rotating, never-setting " $H$ " in the night sky next to a bright point source of light, therefore, may have been interpreted as a headless being with its detached head next to a vulture-like figure nearby and its eternal life related to the fact that it, unlike most other stars, was visible every night. An alternative interpretation of either Vega or the star Deneb (in Cygnus) suggests that it may have inspired the "H"-symbol (Sweatman \& Tsikritsis, 2017: p. 239) though Collins has suggested that Deneb was instead represented by the "Soul Holes" found in two of the enclosures (see Figure 9 and Figure 10 in Collins, 2015). The celestial torso from which the head (i.e. Vega in our interpretation) was severed may also have been inspired by the constellation Orion, also possibly imagined as a headless humanoid figure (Schoch, 2012: p. 55).

The snake-like constellation Draco (Figure 18) may explain the iconography of the many snakes on the T-shaped pillars and on the back of a limestone head found at Nevalı Çori and their seeming migration depicted on some pillars towards the " $\mathrm{H}$ " symbol (e.g. Figure $3(\mathrm{~m})$ ) is neatly explained by Draco's and Boötes' (possibly imagined as a scorpion) proximity to Hercules. The vulture "flying" and "chasing" after the "torso" of Hercules during the hours of the night could have been seen in Cygnus (represented on Pillar 43; Collins, 2017) and we agree that this is more likely than another interpretation which suggests it was meant to represent Sagittarius (Sweatman \& Tsikritsis, 2017: p. 237), as the ${ }^{4}$ Andrew Collins has interpreted the meaning of a bone plaque found at Gobekli Tepe to show a path taken by a person in between two T-shaped pillars and towards the "soul hole", opening through limestone slabs placed at the north ends of Enclosures C and D (Collins, 2015). A similar passage-like iconography is shown in Laroche \#207 (Figure 9), a ligature of "god" and "path" which was the Luwian word for "mountain". 


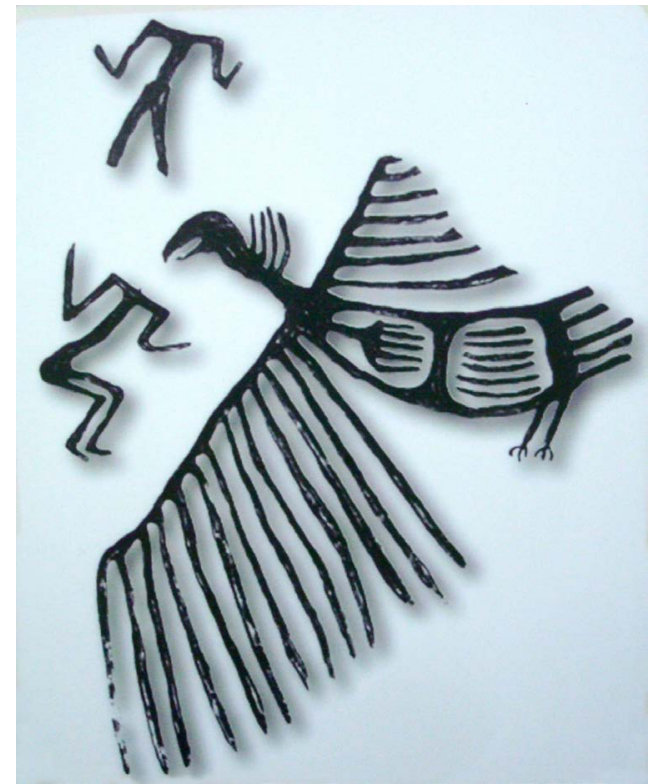

Figure 17. Recreation of a typical wall mural on the north wall of a dwelling at Çatalhöyük showing a vulture and headless human torsos reminiscent of a T-shape with arms and legs. Çatalhöyük site museum, Turkey. Image (2013) courtesy of Robert Schoch and Catherine Ulissey.

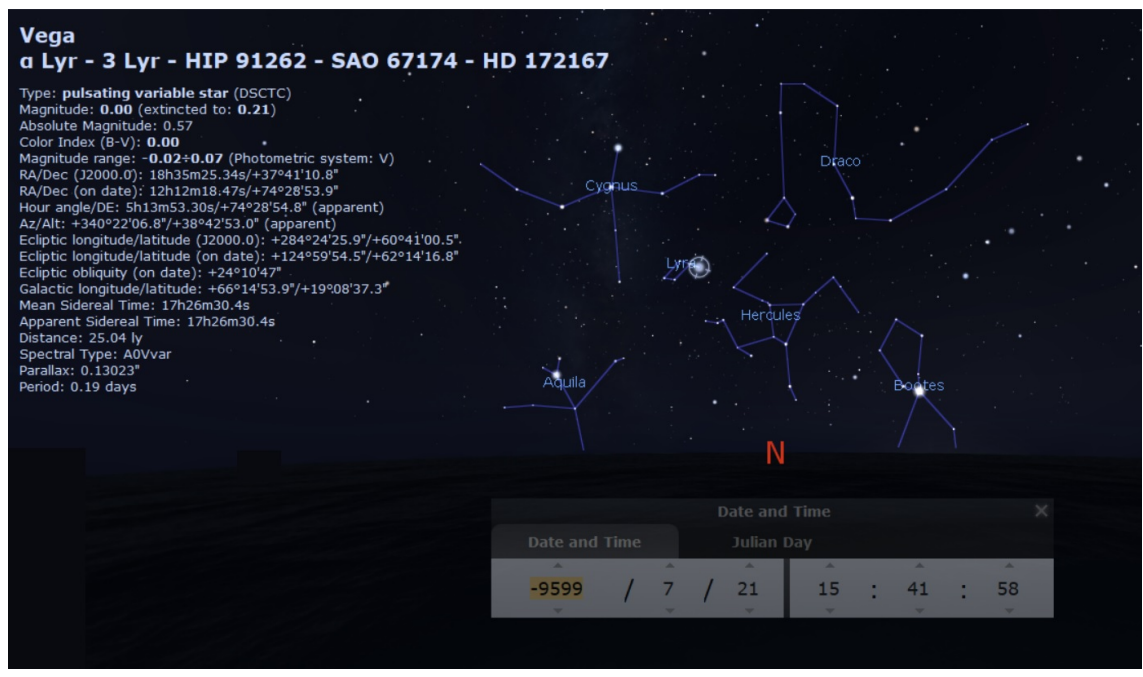

Figure 18. View of the northern star zone from the perspective of Göbekli Tepe in 9600 B.C.E. (Julian year-9599) recreated using Stellarium (version 0.14.3). In the center is the constellation Hercules. The brightest star in the northern star zone Vega is highlighted. The circumpolar region was then populated by the constellations Hercules, Draco, Cygnus, Aquilla, Lyra, and Boötes.

former view is better anchored in our own reconstruction of prehistoric Anatolia's imagined afterlife and better supported by the evidence from Çatalhöyük as Collins (2017) has also noted. This astronomical interpretation is also consistent with the general north-south orientations of enclosures A-D, but the exact positions of Hercules and Vega and the circumpolar constellations in remote times need to be confirmed using astronomical software which can recreate remote 
periods of time (e.g. the Carte du Ciel star mapping project; see Conclusion in De_Lorenzis \& Orofino, 2015).

Another confounding variable may be introduced by tectonic plate movement. Göbekli Tepe is located northwest of the East Anatolian Fault on the Anatolian plate and rotates counterclockwise due to northward push from the Arabian Plate on its eastern end (Cavalié \& Jónsson, 2013, see Figure 1 of citation). This means that the perspective from Anatolian monuments on the ground very slowly rotates west of north relative to the stars in the night sky. The extent to which this may affect alignments to certain stars measured today should be confirmed to be negligible, but it cannot be ignored a priori.

The bull-like T-shaped god statues of Göbekli Tepe are not facing toward the north and the circumpolar region, but are rather turned toward the south. It is possible that the southeastern night sky with the constellation Taurus and Orion's belt asterism, previously suggested by one of us (Schoch, 2012: p. 55), may have been associated with the T-shaped anthropomorphic pillars, and with the cranium of an aurochs. Indeed, the god in question (represented by the central pillars of Enclosure D) was facing toward the region of the sky containing Orion-with its strong belt stars, perhaps represented by the belts on the pillars-and Taurus, the bull or aurochs, on the vernal equinox during Göbekli Tepe times (Schoch, 2012).

It is also possible that prehistoric sky watchers associated either the bull, or the $\mathrm{T}$-shape, or both with the southern hemispheric cross-shaped constellation Crux, which was visible in Anatolia during the $10^{\text {th }}$ Millennium B.C.E. Likewise, the nearby constellation Centaur's inverted " $U$ "-shape may have inspired the same symbol on the belt buckle of Pillar 18, the circular shape of Enclosures $A-D$, and the " $U$ "-shaped stone entrance to Enclosure C to its south. The Milky Way, on which Crux can be seen, forms a starry path to the circumpolar region and this may have been symbolized as the path to the afterlife in the north. T-shaped megalithic pillars on the southern side of the island of Menorca called Taulas surrounded by horseshoe-shaped enclosures built by the Talayotic (Talaiotic) Civilization (circa 1300-800 B.C.E.) were also likely oriented to the low altitude constellations Crux and Centaur (Hoskins et al., 1990) and the sites were abandoned at the same time when Crux disappeared in the northern hemisphere due to Earth-axial precession hinting at a causal connection ${ }^{5}$. The Taulas are a compelling example of an ancient monumental recreation of starry images imagined in the night sky (Figure 19).

Animal Imagery. We may ask if it is necessary to invoke an association with celestial images in order to explain the ancient worship of animal-like gods or gods associated with certain animals. From the perspective of ancient people, the wild aurochs must have been an imposing and ferocious animal (Figure 20)

${ }^{5}$ Klaus Schmidt did not believe that the Bronze Age Menorcan Taulas had any relationship to the similarly T-shaped pillars at Göbekli Tepe because they were made from two stone elements instead of one monolith (Schmidt, 2012, Q \& A session). However, it is not clear if Schmidt had considered that both, despite different manufacture, may have been inspired by the same imagined celestial image or by objects in the sky at all. 

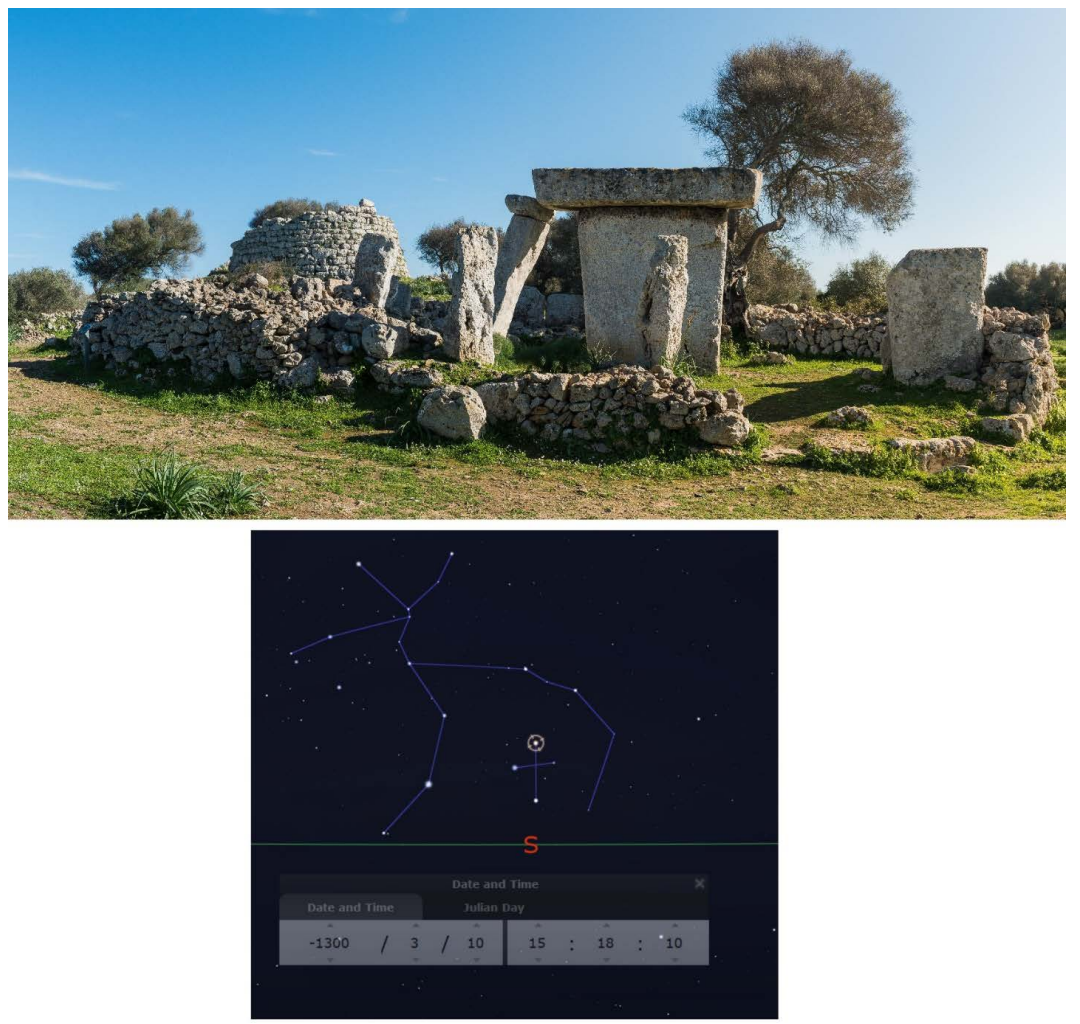

Figure 19. Above, a Taula on Menorca, Spain. Below, a screenshot view of the southern star zone in 1301 B.C.E. (Julian year-1300) from the perspective of Menorca recreated using Stellarium (version 0.14.3). In the center is the Constellation Crux (gamma Crux is highlighted), the southern cross. The constellation Centaur featuring the bright stars Alpha and Beta Centauri forms a horseshoe-like enclosure around Crux and this starry image may have concretely inspired the Taulas. Image (modified) courtesy of Shutter stock, Standard License \#672366646 (January 2, 2019).

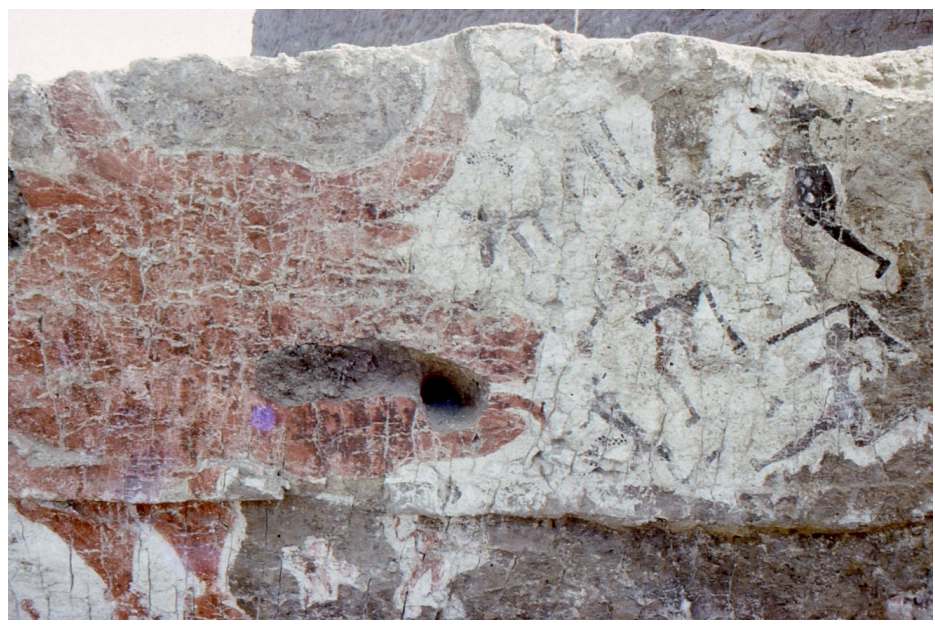

Figure 20. Wall mural at Çatalhöyük showing an aurochs hunt, discovered by James Melaart (1961). Çatalhöyük site museum, Turkey. Image (2013) courtesy of Omar Hoftun, CC BY-SA 3.0,

https://commons.wikimedia.org/wiki/File:Mural_from_\%C3\%87atalh\%C3\%B6y\%C3\%B Ck_excavated_by_James_Mellaart_showing_neolithic_hunters_attacking_an_aurochs_(B os_primigenius)..jpg. 
perfectly suited to symbolize power and this association continued into the Bronze Age when the Anatolian storm god Tešup is seen with a bull (Figure 6 and Figure 8). The vulture could have been uniquely associated with death as this bird could have commonly been witnessed consuming the carcasses of dead animals and humans, unlike other meat-eating animals which eat freshly killed prey. In ancient Egypt, as today, lions bask in the sun, baboons cheer at sunrise, falcons perform acrobatics in front of the glowing sun disk (Robert Bauval, personal communication), and scarab beetles emerge from the sands. Is it the behavior of these animals which turned them into Tefnut, Mehit, Horakhty, Babi, Horus, and Kheper, or was it their imagined likenesses in the starry night sky, that place no ancient human could ever reach, which made them god-like? We think one must consider both aspects of animals, how they behaved and how their likenesses might have been recognized in prominent groups of stars, to reconstruct what likely mattered in each case to ancient peoples' worship of animal-like gods. However, caution must be exercised when attempting to reconstruct what animal or human shapes different ancient cultures at different times imagined certain groups of stars to represent. The ancient Egyptians of the New Kingdom, for example, likely saw the hippopotamus goddess "reret", the scorpion goddess "serket", the falcon god "anu", and the ox thigh "mesekhtiu" in the circumpolar star group, while Claudius Ptolemaeus' Almagest (Alexandria, $2^{\text {nd }}$ century C.E.) listed Draco, Ursa major and minor, and Boötes (Lull \& Belmonte, 2009, Chapter 6, pp. 164-168).

Conclusions. In summary, we have drawn a semantic link between the dominant symbolism of Göbekli Tepe, T-pillars and H-symbols, and the words for god and gate in the Luwian script. Thus, the central pillars inside Göbekli Tepe's enclosures were meant to be gods, or one god, associated with bulls and the $\mathrm{H}$-symbols on them were meant to explicitly mark them as such, i.e. beings, or one supreme spiritual being, presiding over the imagined path from life to death in the form of a symbolic gateway. This link confirms what others have long suspected: That Göbekli Tepe, at least in part, served as a temple site. The details of the rituals practiced there (as well as other activities) may not come to light, if ever, until the remaining circles are excavated; however, our analysis suggests that a passage rite involving decapitation of the deceased, and thus resurrection from the realm of the dead, may have been involved. The role of the god associated with a bull was that of the gatekeeper between the realms of the living and the dead and so it is possible, we might speculate, that resurrection in the form of decapitation required a price to be paid, possibly a sacrifice which was enacted inside of the circles. This may have been a spectacle watched by pilgrims to the site, and the incentive to make the long journey to Göbekli Tepe from the surrounding camps would have been the feasts held made from the animals sacrificed on these prehistoric altars.

From these early beginnings, the essential elements of this ritual would have eventually been "domesticated" at the later settlements of the region in a more 
ritualized form of skull preservation and reverence as part of staying connected to ancestors. The roots of this ancestral worship however bear the marks of hunters and nomadic gatherers, not settled farmers. Only later, when edible plants were cultivated, a more relevant to farming, likewise astronomically inspired, shift of focus from the stars in the north and south to the Sun and Moon in the east and west may have occurred explaining the variant circle orientations of Enclosures A and F, the latter of which ${ }^{14}$ Carbon-dates to the late $9^{\text {th }}$ Millennium B.C.E. (De Lorenzis \& Orofino, 2015: pp. 43-47). A similar more symbolic, and less actual, reenactment of a primeval, more physical, ritual would be the Mouth Opening Ceremony of Dynastic Egypt as the stylized version of the Statuette Making Ritual or the ritual killing and revival of an Egyptian king during the Heb-Sed festival as the stylized, i.e. more civilized, version of the actual killing of an ageing chieftain having to prove that he can still lead a hunt to procure food for his tribe or else be killed (Helck, 1987, Chapter 2, page 5).

The advent of the Neolithic Revolution in this model rested on a unifying concept of a superhuman, yet both human-like and bull-like spiritual being, a god, which brought otherwise scattered people into one location to build a monument for worship, perform rituals for the afterlife, and feast. Why this unifying spirituality arose during and after the end of the Younger Dryas in southeast Anatolia and was eventually buried together with the monumental creations expressing it remains unknown. It may have been epic ecological changes caused by a wide-spread catastrophe (Schoch, 2012: p. 99-103; Sweatman \& Tsikritsis, 2017: p. 243), it may have been a charismatic shaman or tribal leader, and even distant origin cultural transfer has been proposed including from Australia (Fenton, 2017) ${ }^{6}$. Whatever inspired it-fear, charisma, or cultural transfer from elsewhere-the congregation it catalyzed made innovation ${ }^{7}$, division of labor, and team work more likely, eventually (circa $8^{\text {th }}$ millennium B.C.E. or earlier) setting the stage for the domestication of plants (Demiral, 2016: pp. 131-133) and animals by larger groups of people united by the same beliefs conveyed by its powerful spiritual symbolism. This, then, may have been the real catalyst in Cauvin's model of the origins of agriculture: The communal spirit of interacting in a large group captivated by iconic symbols recognized by many as opposed to hunting in the isolation of small bands composed only of a few closely-nit family members. It is this power of symbols which we think was the driving force behind the desire to record them in stone and the word for God fittingly would be the first such symbol recorded, making it the first word in recorded history.

${ }^{6}$ Bruce Fenton has suggested a close match between the $\mathrm{H}$-symbols carved onto Pillars 18 and 28 at Göbekli Tepe and an Australian Aboriginal symbol for exchanging knowledge seen on some Churinga stones.

${ }^{7}$ For example, stone cutting and transporting technology and the insight by accidental discovery that the seeds of edible wild grasses could be planted in the soil in the spring to produce a new edible plant in the fall, thus providing a renewable food source. 


\section{Dedication}

We would like to dedicate this paper to Professor Dr. Klaus Schmidt, the discoverer of Göbekli Tepe's megalithic stone circles, who tragically passed away on 20 July 2014.

\section{Conflicts of Interest}

The authors declare no conflicts of interest regarding the publication of this paper.

\section{References}

Ames, K. M. (1994). The Northwest Coast: Complex Hunter-Gatherers, Ecology, and Social Evolution. Annual Review of Anthropology, 23, 209-229. https://doi.org/10.1146/annurev.an.23.100194.001233

Baines, J. (2004). The Earliest Egyptian Writing: Development, Context, Purpose. In S. D. Houston (Ed.), The First Writing: Script Invention as History and Process (pp. 150-189). Cambridge: Cambridge University Press.

Banning, E. B. (2011). So Fair a House: Göbekli Tepe and the Identification of Temples in the Pre-Pottery Neolithic in the Near East. Current Anthropology, 52, 619-660. https://doi.org/10.1086/661207

Bouckaert, R., Lemey, P., Dunn, M., Greenhill, S. J., Alekseyenko, A. V., Drummond, A. J., Gray. R. D., Suchard, M. A., \& Atkinson, Q. D. (2012). Mapping the Origins and Expansion of the Indo-European Language Family. Science, 337, 957-960. https://doi.org/10.1126/science.1219669

Cauvin, J., (2000). The Birth of the Gods and the Origins of Agriculture. Cambridge, UK: Cambridge University Press. (English Translation by Trevor Watkins)

Cavalié, O., \& Jónsson, S. (2013). Block-Like Plate Movements in Eastern Anatolia Observed by InSAR. Geophysical Research Letters, 41, 26-31. https://agupubs.onlinelibrary.wiley.com/doi/epdf/10.1002/2013GL058170 https://doi.org/10.1002/2013GL058170

Collins, A. (2014). Göbekli Tepe-Genesis of the Gods, the Temple of the Watchers and the Discovery of Eden. Rochester, VT: Bear \& Company.

Collins, A. (2015). First Pictorial Representation of Göbekli Tepe T-Pillars Found on Tiny Bone Plaque. http://www.andrewcollins.com/page/articles/plaque.htm

Collins, A. (2017). Göbekli Tepe's Vulture Stone: A Warning across Time or Signpost to the Land of the Dead? Putting into Perspective the Carved Imagery on Göbekli Tepe's Pillar 43 in Enclosure D. http://www.andrewcollins.com/page/articles/sagittarius.htm

Damerow, P. (2006). The Origins of Writing as a Problem of Historical Epistemology. Cuneiform Digital Library Journal, 2006, 1.

De Lorenzis, A., \& Orofino, V. (2015). New Possible Astronomic Alignments at the Megalithic Site of Göbekli Tepe, Turkey. Archeological Discovery, 3, 40-50.

https://doi.org/10.4236/ad.2015.31005

Demiral, S. (2016). Recent Researches in Interdisciplinary Sciences (Chapter 10, pp. 130-138). Sofia: St. Kliment Ohridsky University Press. https://www.researchgate.net/publication/311400755_Domestication_of_Wheat_in_An atolia_from_the_Neolithic_Period_to_the_Iron_Age

Ercan, M. (2015). Signs of World's First Pictograph Found in Göbeklitepe. 
http://www.hurriyetdailynews.com/signs-of-worlds-first-pictograph-found-in-gobeklit epe--85438

Fenton, B. (2017). A Global Aboriginal Australian Culture? The Proof at Göbekli Tepe. New Dawn Magazine, 2017. http://ancientnews.net/2017/10/13/a-global-aboriginal-australian-culture-the-proof-atgobekli-tepe/

Goedegebuure, P. (2016). Luwian Hieroglyphs: An Indigenous Anatolian Syllabic Script. Lecture Given at the Oriental Institute. https://www.youtube.com/watch?v=fOd_hodh7Mc

Goedegebuure, P. (2017). Hittite Anatolia Cornucopia of Cultures in Contact. News \& Notes Member Magazine, 234, 4-9. https://oi.uchicago.edu/sites/oi.uchicago.edu/files/uploads/shared/docs/Publications/n n234.pdf

Goldwasser, O. (2016). The Birth of the Alphabet from Egyptian Hieroglyphs in the Sinai Desert. In D. Ben-Tor (Ed.), Pharaoh in Canaan: The Untold Story (pp. 166-170). Exhibition Catalogue. Jerusalem: Israel Museum.

https://www.academia.edu/38014205/Goldwasser_O._2016._The_Birth_of_the_Alphab et_from_Egyptian_Hieroglyphs_in_the_Sinai_Desert_in_Daphna_Ben-Tor_ed._Phara oh_in_Canaan_the_untold_story._Exhibition_catalogue._Jerusalem_Israel_Museum

Gresky, J., Haelm, J., \& Clare, L. (2017). Modified Human Crania from Göbekli Tepe Provide Evidence for a New Form of Neolithic Cult. Science Advances, 3, e1700564. http://advances.sciencemag.org/content/3/6/e1700564/tab-pdf https://doi.org/10.1126/sciadv.1700564

Helck, W. (1987). Untersuchungenzur Thinitenzeit. Wiesbaden: Otto Harrassowitz Verlag.

Hodder, I. (2011). The Role of Religion in the Neolithic of the Middle East and Anatolia with Particular Reference to Çatalhöyük. Paléorient, 37, 111-122. https://doi.org/10.3406/paleo.2011.5442

Hodder, I. (2012). Çatalhöyük. A Summary of Recent Work Concerning Architecture. In B. Söğüt (Ed.), Festschrift for Ahmet A. Tirpan (pp. 303-314). İstanbul: Ege Yayınları. https://static1.squarespace.com/static/53568703e4b0feb619b78a93/t/53679823e4b0124f 24031679/1399298083752/catalhoyuk-a-summary-of-recent-work-concerning-architec ture.pdf

Hoskins, M., Hochsieder, P., \& Knösel, D. (1990). The Orientation of the Taulas of Menorca (2): The Remaining Taulas. Archeoastronomy, 21, 37-48.

Laroche, E. (1960). Les Hiéroglyphes Hittites. Paris: Éditions du Centre National de la Recherche Scientifique (CNRS).

Lull, J., \& Belmonte, J. A. (2009). In Search of Cosmic Order. Cairo: Supreme Council of Antiquities Press.

Magli, G. (2013). Possible Astronomical References in the Project of the Megalithic Enclosures of Göbekli Tepe. Cornell University Library Online.

Magli, G. (2016). Sirius and the Project of the Megalithic Enclosures at Gobekli Tepe. Nexus Network Journal, 18, 337-346. https://doi.org/10.1007/s00004-015-0277-1 https://doi.org/10.1007/s00004-015-0277-1d

Putney, A. (2014). Resonance at Göbekli Tepe, Turkey. http://www.human-resonance.org

Sandars, N. K. (1979). The Religious Development of Some Early Societies. In P. R. S. Moorey (Ed.), The Origins of Civilization (pp. 103-127). Oxford: Clarendon Press.

Schmidt, K. (2000). Göbekli Tepe, Southeastern Turkey. A Preliminary Report on the 
1995-1999 Excavations. Paléorient, 26, 45-54. https://doi.org/10.3406/paleo.2000.4697

Schmidt, K. (2011). Göbekli Tepe: A Neolithic Site in Southeastern Anatolia. In S. R. Steadman, \& G. McMahon (Eds.), The Oxford Handbook of Ancient Anatolia (pp. 917-933). Oxford: Oxford University Press.

Schmidt, K. (2012). Lecture, Sanliurfa. https://youtu.be/J1PDX0NjwsA

Schoch, R. (2012). Forgotten Civilization: The Role of Solar Outbursts in Our Past and Future. Rochester, VT: Inner Traditions.

Schoch, R. M. (2017). Controversies Concerning the End of the Last Ice Age. In R. M. Schoch, \& R. Bauval (Eds.), Origins of the Sphinx: Celestial Guardian of Pre-Pharaonic Civilization (pp. 445-466). Rochester, VT: Inner Traditions.

Senner, W. (1991). The Origin of Writing. Lincoln: University of Nebraska Press.

Smith, M. (2009). V. Gordon Childe and the Urban Revolution: A Historical Perspective on a Revolution in Urban Studies. Town Planning Review, 80, 3-29.

http://www.public.asu.edu/ mesmith9/1-CompleteSet/MES-09-Childe-TPR.pdf https://doi.org/10.3828/tpr.80.1.2a

Sweatman, M. B., \& Tsikritsis, D. (2017). Decoding Göbekli Tepe with Archaeoastronomy: What Does the Fox Say? Mediterranean Archaeology and Archaeometry, 17, 233-250.

Waal, W. (2013). Writing in Anatolia. The Origins of the Anatolian Hieroglyphs and the Introduction of the Cuneiform Script. Altorientalische Forschungen, 39, 287-315.

Zangger, E. (2016). The Luwians: A Lost Civilization Comes Back to Life. Lecture at Klosters. https://youtu.be/1DNyA90f_aw 